\section{Kidney \\ Blood Pressure Research}

\title{
Urinary Metalloproteinases-9 and -2 and Their Inhibitors TIMP-1 and TIMP-2 are Markers of Early and Long-Term Graft Function After Renal Transplantation
}

\author{
Ewa Kwiatkowska ${ }^{a} \quad$ Leszek Domanski ${ }^{a} \quad J o a n n a ~ B o b e r^{b} \quad K^{2} z y s z t o f$ Safranow ${ }^{c}$ \\ Maciej Romanowskid Andrzej Pawlike Sebastian Kwiatkowski ${ }^{f}$ \\ Kazimierz Ciechanowski ${ }^{\mathrm{a}}$
}

${ }^{a}$ Clinical Department of Nephrology, Transplantology and Internal Medicine; ${ }^{b}$ Department of Medical

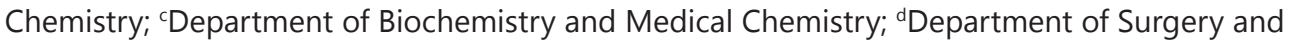
Transplantology; ${ }^{\text {Department }}$ of Physiology; ${ }^{\text {DDepartment }}$ of Obstetrics and Gynecology, Pomeranian Medical University, Szczecin, Poland

\section{Key Words}

Kidney transplantation $•$ Graft function $•$ Matrix metalloproteinases $•$ Matrix metalloproteinase inhibitors

\begin{abstract}
Background/Aims: Renal ischemia-reperfusion (I-R) injury (IRI) is an inseparable feature of organ transplantation and may have a negative impact on the graft, its function and survival. Acute tubular necrosis, which is reversible thanks to the regenerative capacity of renal tubular epithelial cells, is the main cause of acute renal failure secondary to IRI. MMP-2 and MMP-9 are proteolytic enzymes involved in digesting proteins that are components of the extracellular matrix (ECM) and the basement membrane of the nephrons. This way post-reperfusion MMP activation allows the inflammatory process to spread. Methods: In our studies, we focused on identifying whether the concentrations of MMP-2 and MMP-9 and their natural inhibitors TIMP-1 and TIMP-2 in urine sample at day 1 and day 30 as well as after 12 months following renal transplantation are markers of early and long-term renal function during meanly fiveyears observation. Moreover, in urine sampled at months 6 and 12 after renal transplantation, we determined the content of TGF- $\beta$ as a graft fibrosis indicator. Results: MMP- 9 concentration in the early post-transplant period is a major marker of early and long-term function of the transplanted kidney. Its increased concentration was correlated with lesions related to tubular atrophy and fibrosis in renal biopsies performed at months 3 and 12 after transplantation. Its concentration is correlated with TGF- $\beta$ content in a later period. Conclusions: TIMP- 1 and
\end{abstract}




\section{Kidney Blood Pressure Research}

Kidney Blood Press Res 2016;41:288-297

DOI: 10.1159/000443431

Published online: May 06, 2016

(C) 2016 The Author(s). Published by S. Karger AG, Base

www.karger.com/kbr

-2 are primarily markers of an early function of the transplanted kidney. Early post-transplant concentration of MMP-2 is a marker of proteinuria in early and long-term post-transplant periods.

\section{Introduction}

Renal ischemia-reperfusion (I-R) injury (IRI) is an inseparable feature of organ transplantation and may have a negative impact on the graft, its functions and survival. This phenomenon is still being studied. It involves the activation of neutrophils, endothelium and thrombocytes, oxidative stress, complement activation and upregulation of cytokines and chemokines [1]. The scale of renal I-R injury is determined by the severity of the inflammatory process induced. Recently, it has been discovered that vascular endothelial damage and increased tension of vessels in ischemia-reperfusion are of considerable significance [2-4]. Decreased blood flow in peritubular vessels occurs within minutes of reperfusion [5]. Evidence to the role of vascular endothelial damage in renal ischemiareperfusion injury has been found in experimental research, where administration of endothelial nitric oxide synthase prevented injury related to IRI. Ischemia leads to damage to endothelial cells, which upregulates various adhesion molecules: ICAM-1, P-selectin and E-selectin $[6,7]$. These favour neutrophil adhesion and migration to the extravascular space. Having found themselves in the extravascular space, neutrophils release free radicals, proteases and elastases, thus causing a further increase in permeability of the vessels, which enables other inflammatory cells, such as macrophages, B cells and T cells, to migrate to the renal parenchyma. The inflammatory process exacerbates the ischemia and injury and, as a result, long-term renal fibrosis. The factors that activate neutrophils, but also facilitate their migration and that of other inflammatory cells, will determine the scale of IRI and the early and long-term function of the transplanted kidney.

MMP-2 and -9 are proteolytic enzymes and members of the gelatinase group. They are primarily involved in digesting type IV collagen as well as lamina, proteoglycans and fibronectin. These proteins are components of the extracellular matrix. Apart from the ECM, metalloproteinases also digest the basement membrane of type IV collagen-rich vessels of the nephrons. By digesting the basement membrane, they destroy the physiological barrier that makes it impossible for cells to migrate from the lumen of the vessel to the extravascular space. Similarly, by digesting the ECM, they destroy the interstitium, with which they facilitate cell migration and also the release of various growth factors stored in the ECM. MMP-9 is indirectly involved in activating granulocytes and facilitating their migration. Firstly, it is an activator of IL-8, which is activated by the cleavage and removal of a short amino acid sequence. IL-8 is a recognized neutrophil chemotactic factor. Secondly, MMP-9 activates a peptide originating from endothelial cells that activates neutrophils - epithelial cell derived neutrophil activating peptide-78(ENA-78). This allows for further spreading of the inflammatory process $[8,9]$.

\section{Materials and Methods}

\section{Patients}

Our analysis covered 87 patients who underwent kidney transplantation in the Clinical Department of Surgery and Transplantology of the Pomeranian Medical University in Szczecin between 2006 and 2008, who were subsequently under the care of the Clinical Department of Nephrology, Transplantology and Internal Medicine. The patients were observed for an average of 30 months (a minimum of 0.5 months and a maximum of 60 months). Unfortunately, not all of the patients were subjected to long-term observation, as some of them changed their transplantation centre for one closer to their domicile. The observation included attending the patients after their kidney transplantation procedure and making regular follow-up appointments throughout the entire post-transplant period. Upon kidney transplantation, all of the patients received tri- 


\section{Kidney Blood Pressure Research}

Kwiatkowska/Domanski/Bober/Safranow/Romanowski/Pawlik/Kwiatkowski/Ciechanowsk: Urinary Metalloproteinases and Their Inhibitors After Renal Transplantation

ple immunosuppressive therapy with glucocorticosteroids, a calcineurin inhibitor and mycophenolan mophetil. Patient data are listed in Table 1.

\section{Methodology}

After kidney

transplantation, urine was sampled at day 1 , day 3 and after 12 months. In patients who did not urinate because of delayed graft function, the first sample was collected when the amount of urine produced exceeded $500 \mathrm{ml}$ per day. Urine samples were centrifuged at $4000 \mathrm{rpm}$ for 10 minutes, and sediment-free urine was stored at a temperature of $-80{ }^{\circ} \mathrm{C}$ prior to analysis. The activities of MMP-9/2 and TIMP-1/2 were determined using the enzyme-linked immunosorbent assay (ELISA) using R\&D Systems USA kits, with the application of specific polyclonal antibodies. Assay sensitivity was $0.156 \mathrm{ng} / \mathrm{mL}$ for MMP-9. The concentration of creatinine in the urine was assessed in a reaction with picric acid, after dilution of the urine by 50 times. Activity of MMP and TIMP were calculated in relation to creatinine concentration. For all readings, the ELx808 microplate reader by BIO-TEK Instruments, Inc was used. TGF- $\beta 1$ content in post-transplant patients' urine was determined using the enzyme-linked immunosorbent assay (ELISA) (with Quantikine kits by R\&D Systems USA) according to the manufacturer's instructions. The assay results were read using the ELISA reader (EL 808 by BIO-TEK Instruments, Inc.) at a wavelength of $450 \mathrm{~nm}$. Assay sensitivity was lower than $1.7 \mathrm{pg} / \mathrm{ml}$. For each patient, the levels of creatinine and urea in blood serum were determined, a general urinalysis was carried out, and the calcineurin inhibitor content was identified both when sampling the urine and during each follow-up appointment after kidney transplantation. The GFR was estimated using the CKD-EPI Formula with the help of the National Kidney Foundation calculator. Moreover, such information was analyzed as the donor's details, cold ischemia time, HLA and PRA (panel reactive antibody) disparity, and the recipient's details such as the cause of renal failure and the duration of renal replacement therapy, gender, age, weight, and the occurrence of delayed graft function (DGF) - the need for hemodialysis (HD) within 7 days of kidney transplantation. Furthermore, some of the patients received protocol biopsies at months 3 and 12. For patients demonstrating prolonged delayed graft function with increased risk of acute rejection, biopsies were performed during the first 14 days after transplantation.

\section{Statistical analysis}

We used STATISTICA 9 software (StatSoft, Tulsa, USA) for analysis. As Shapiro-Wilk's test showed that the distributions of MMP-2/9, TIMP-2/9 and TGF- $\beta$ concentration were significantly different from normal $(p<0.05)$, we used a nonparametric Mann-Whitney $U$ test, a Wilcoxon signed-rank test and Spearman's rank correlation test for the statistical analysis. 


\section{Kidney \\ Blood Pressure Research}

Kidney Blood Press Res 2016;41:288-297

DOI: 10.1159/000443431

Published online: May 06, 2016

(c) 2016 The Author(s). Published by S. Karger AG, Base www.karger.com/kbr

Kwiatkowska/Domanski/Bober/Safranow/Romanowski/Pawlik/Kwiatkowski/Ciechanowsk: Urinary Metalloproteinases and Their Inhibitors After Renal Transplantation
Results

MMP 9 concentration in urine at day 1 and 3 months after renal transplantation

MMP 9 concentration determined at day 1 (Table 2) was significantly negatively correlated with creatinine clearance after renal transplantation determined at day 1 , as
Table 2. The values of MMP 2, MMP9, TIMP 1 and TIMP 2 concentrations [ng/ $\mathrm{mL}$ ] evaluated in 1 day, 3 and 12 month after renal transplantation

\begin{tabular}{lcccccc}
\hline & $\mathrm{N}$ & MEAN & MEDIAN & MIN & MAX & SD \\
\hline TIMP1-1D & 68 & 3.830382 & 1.852 & 0.082 & 15.729 & 4.126185 \\
TIMP1-3M & 55 & 1.183964 & 0.386 & 0 & 8.517 & 1.963094 \\
TIMP1-1Y & 42 & 0.560524 & 0.3555 & 0.033 & 4.536 & 0.936761 \\
\hline TIMP2-1D & 68 & 0.443088 & 0.161 & 0.058 & 4.247 & 0.784533 \\
TIMP2-3M & 55 & 0.406182 & 0.151 & 0 & 3.252 & 0.617961 \\
TIMP2-1Y & 42 & 0.426333 & 0.1765 & 0.054 & 4.283 & 0.725393 \\
\hline MMP2-1D & 66 & 11.92005 & 2.8505 & 0 & 113.522 & 21.20249 \\
MMP2-3M & 54 & 23.70848 & 1.8465 & 0 & 597.9 & 89.27572 \\
MMP2-1Y & 42 & 16.0169 & 1.3975 & 0 & 167.54 & 41.55821 \\
\hline MMP9-1D & 67 & 5.109209 & 0.869 & 0 & 66.524 & 12.81709 \\
MMP9-3M & 55 & 0.919509 & 0.239 & 0 & 9.477 & 1.641765 \\
MMP9-1Y & 42 & 1.278762 & 0.269 & 0 & 13.483 & 2.791961 \\
\hline TIMP-1,2 tissue inhibitor of metalloproteinases-1,2; MMP-2,9 metallo- \\
proteinase-2,9, 1D first day, 3M third month, 1Y first year
\end{tabular}

Table 3. Correlation between GFR and MMP 9 and TIMP-1 concentrations in urine at day 1 and 3 month after renal transplantation

\begin{tabular}{lccccc}
\hline GFR & $\mathrm{N}$ & $\begin{array}{c}\text { Correlation with } \\
\text { MMP-9 at day 1 after } \\
\text { transplantation }\end{array}$ & $\begin{array}{c}\text { Correlation with } \\
\text { MMP-9 at month 3 } \\
\text { after transplantation }\end{array}$ & $\begin{array}{c}\text { Correlation with } \\
\text { TIMP-1 at day 1 after } \\
\text { transplantation }\end{array}$ & $\begin{array}{c}\text { Correlation with } \\
\text { TIMP-1 at month 3 } \\
\text { after transplantation }\end{array}$ \\
\hline $\mathrm{D}$ 1 & 56 & $\mathrm{p}=0.0036 ; \mathrm{R}=-0.27$ & $\mathrm{NS}$ & $\mathrm{p}=0.0001 ; \mathrm{R}=-0.48$ & $\mathrm{NS}$ \\
$\mathrm{D} 7$ & 46 & $\mathrm{NS}$ & $\mathrm{p}=0.00069 ; \mathrm{R}=-0.48$ & $\mathrm{p}=0.0053-\mathrm{r}=-0.36$ & $\mathrm{p}=0.004 ; \mathrm{R}=-0.41$ \\
$\mathrm{P}$ 14 & 48 & $\mathrm{NS}$ & $\mathrm{p}=0.043-\mathrm{r}=-0.29$ & $\mathrm{P}=0.02 ; \mathrm{R}=-0.29$ & $\mathrm{p}=0.039-\mathrm{r}=-0.29$ \\
M 3 & 51 & & $\mathrm{NS}$ & $\mathrm{P}=0.06 ; \mathrm{R}=-0.26$ \\
Y 1 & 58 & $\mathrm{P}=0.014 ; \mathrm{R}=-0.31$ & $\mathrm{P}=0.055 ; \mathrm{R}=-0.27$ & $\mathrm{NS}$ & $\mathrm{NS}$ \\
Y 2 & 47 & $\mathrm{P}=0.023 ; \mathrm{R}=-0.33$ & $\mathrm{P}=0.015 ; \mathrm{R}=-0.36$ & $\mathrm{NS}$ & $\mathrm{P}=0.038 ; \mathrm{R}=-0.31$ \\
Y 3 & 39 & $\mathrm{P}=0.047 ; \mathrm{R}=-0.32$ & $\mathrm{NS}$ & $\mathrm{NS}$ & $\mathrm{NS}$ \\
Y 4 & 33 & $\mathrm{P}=0.08 ; \mathrm{R}=-0.3$ & $\mathrm{P}=0.023 ; \mathrm{R}=-0.41$ & $\mathrm{NS}$ \\
\hline
\end{tabular}

GFR-glomerular filtration rate, MMP-9 metalloproteinase 9, TIMP-9- tissue inhibitor of matrix metalloproteinase, NS- not statistically significant, D-day, M-month, Y-year.

well as after years 1, 2, 3 and 4. MMP-9 concentration in urine sampled 3 months after renal transplantation was significantly negatively correlated with creatinine clearance at days 7 and 14 as well as years 1, 2 and 4 after renal transplantation (Table. 3). MMP-9 concentration in urine at month 12 after renal transplantation was not correlated with renal function expressed as creatinine clearance (GFR) throughout the entire observation period. MMP-9 concentration determined in urine at day 1 was positively related to the occurrence of interstitial fibrosis $\mathrm{CI} p$ $=0.097 ; \mathrm{R}=0.46$ and tubular atrophy CT $p=0.07 ; \mathrm{R}=0.40 ; \mathrm{N}=14$ in a renal biopsy performed at month 3 after renal transplantation and with tubular atrophy in a biopsy performed 12 months after renal tx $(p=0.085 ; \mathrm{R}=0.40 ; \mathrm{N}=19)$ though the relationship was not statistically significant.

TIMP-1 concentration determined at day 1 and month 3

TIMP-1 determined at day 1 was significantly negatively correlated with creatinine clearance at days 1, 7 and 14 after renal transplantation. TIMP- 1 determined at month 3 after transplantation was significantly negatively correlated with creatinine clearance at days 7 and 14, at month 3 and after 2 years following renal transplantation (Table. 3). Although TIMP-1 concentration at month 12 had a negative impact on creatinine clearance in years 1 and 2 after renal transplantation, the correlation was not statistically significant. In the Mann-Whitney $U$ test, TIMP- 1 concentration determined at day 1 and month 3 was higher in the group demonstrating DGF ( $p=0.03$ and $p=0.07$ ), while TIMP- 2 concentration in urine sampled at month 3 was higher in the group 


\section{Kidney Blood Pressure Research}

Kidney Blood Press Res 2016;41:288-297

DOI: 10.1159/000443431

Published online: May 06, 2016

C 2016 The Author(s). Published by S. Karger AG, Base

www.karger.com/kbr

Kwiatkowska/Domanski/Bober/Safranow/Romanowski/Pawlik/Kwiatkowski/Ciechanowsk:

Urinary Metalloproteinases and Their Inhibitors After Renal Transplantation with DGF $(p=0.003)$. The activities of MMP-9 and TIMP-1 in each of the periods assessed were positively correlated with each other. At day $1 \mathrm{p}=0.000054$, $\mathrm{R}=0.41$, at month 3 $\mathrm{p}=0.0003, \quad \mathrm{R}=0.46$ at 1 year $\mathrm{p}=0.002$, $\mathrm{R}=0.45$.
Table 4. Correlation between GFR and TIMP-2 concentration

\begin{tabular}{lccc}
\hline GFR & $\mathrm{N}$ & $\begin{array}{c}\text { Correlation with TIMP-2 } \\
\text { at month 3 after } \\
\text { transplantation }\end{array}$ & $\begin{array}{c}\text { Correlation with TIMP-2 } \\
\text { at month 12 after } \\
\text { transplantation }\end{array}$ \\
\hline Day 7 & 46 & $\mathrm{p}=0.002 ; \mathrm{R}=-0.43$ & $\mathrm{NS}$ \\
Day 14 & 48 & $\mathrm{p}=0.014-\mathrm{r}=-0.35$ & $\mathrm{NS}$ \\
Month 3 & 35 & $\mathrm{NS}$ & $\mathrm{P}=0.004 ; \mathrm{R}=-0.46$ \\
Year 1 & 41 & $\mathrm{NS}$ & $\mathrm{p}=0.015-\mathrm{r}=-0.37$ \\
Year 2 & 31 & $\mathrm{P}=0.043 ; \mathrm{R}=-0.30$ & $\mathrm{P}=0.049 ; \mathrm{R}=-0.35$
\end{tabular}

GFR-glomerular filtration rate, TIMP-2 tissue inhibitor of metalloproteinases-2, NS- not statistically significant.

TIMP-2

TIMP-2 concentration determined at day 1 was not correlated with creatinine clearance during any of the periods observed. TIMP-2 concentration in urine at month 3 after renal transplantation was significantly negatively correlated with creatinine clearance both soon after renal transplantation (days 7 and 14) and during long-term observation (year 2). TIMP- 2 concentration determined at month 12 after renal transplantation was significantly negatively correlated with creatinine clearance in years 1 and 2 after renal transplantation (Table. 4).

\section{$M M P-2$}

MMP-2 concentration was not correlated with creatinine clearance in any of the periods observed. MMP- 2 sampled at month 3 was correlated with the value of proteinuria in a single urine sample at days 1 and 3 as well as month $12(p=0.01, \mathrm{R}=0.37 ; p=0.027, \mathrm{R}=0.31$; $\mathrm{p}=0.0015, \mathrm{R}=0.43$ ). When MMP-2 and MMP-9 concentration determinations were made, namely at day 1 , month 3 and month 12 , the activities of MMP-2 and -9 were positively correlated with each other $(p=0.02, \mathrm{R}=0.27 ; p=0.000008, \mathrm{R}=0.56 ; p=0.048, \mathrm{R}=0.3)$.

\section{TGF- $\beta$}

Moreover, MMP-9 concentration in urine at day 1 was positively correlated with TGF- $\beta$ urine concentration determined at month 12 after renal transplantation $(R=0,37$, $\mathrm{p}=0.04)$. Fig. 1 TIMP-1 sampled at day $1(\mathrm{R}=0.34, \mathrm{p}=0.035)$ and month $3(\mathrm{R}=0.41, \mathrm{p}=0.011)$ was positively correlated with TGF- $\beta$ concentration sampled at month 6 and similarly, TIMP-2 sampled at month 3 was correlated with TGF- $\beta$ concentration at month 6 after transplantation ( $\mathrm{R}=0.33$, $\mathrm{p}=0.049)$. Fig. 2,3,4

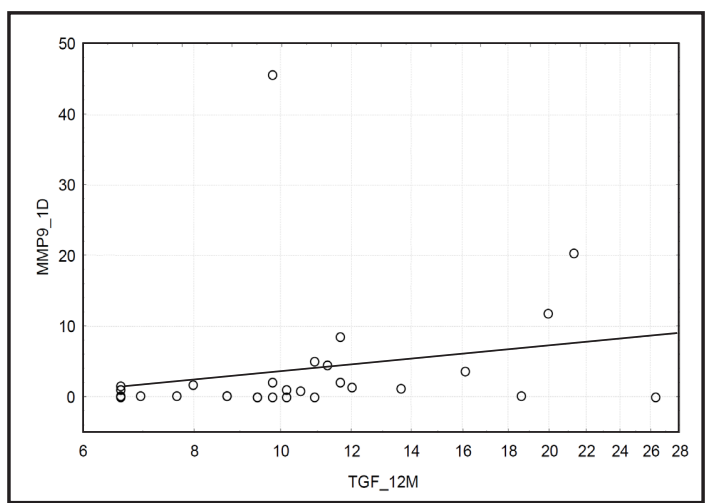

Fig. 1. The correlation between urine concentration of MMP-9 at first day and TGF- $\beta$ at 12 month $\mathrm{R}=0.37$, $\mathrm{p}=0.04$.

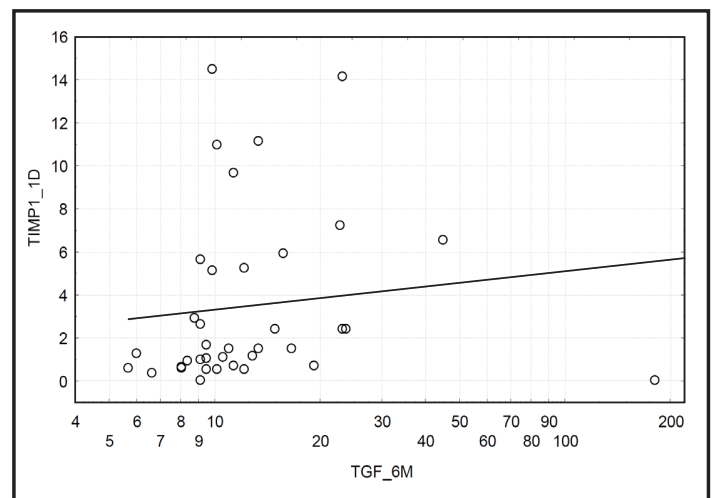

Fig. 2. The correlation between urine concentration of TIMP- 1 at first day and TGF- $\beta$ at 6 month $\mathrm{R}=0.34$, $\mathrm{p}=0.035$. 


\section{Kidney \\ Blood Pressure Research}

Kidney Blood Press Res 2016;41:288-297

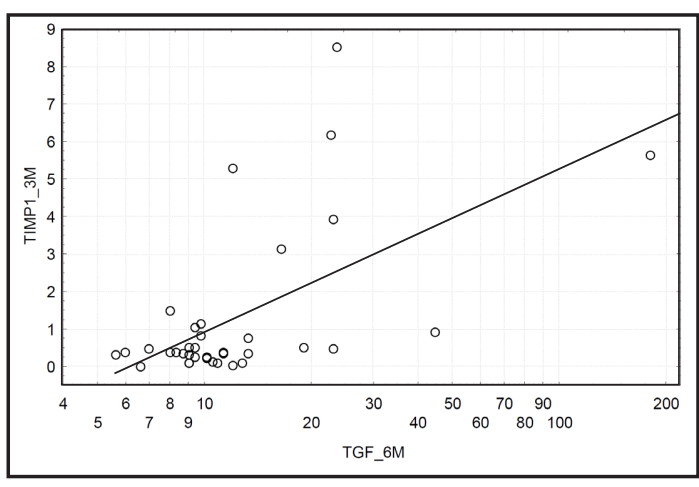

Fig. 3. The correlation between urine concentration of TIMP- 1 at first day and TGF- $\beta$ at 6 month $\mathrm{R}=0.41$, $\mathrm{p}=0.011$.

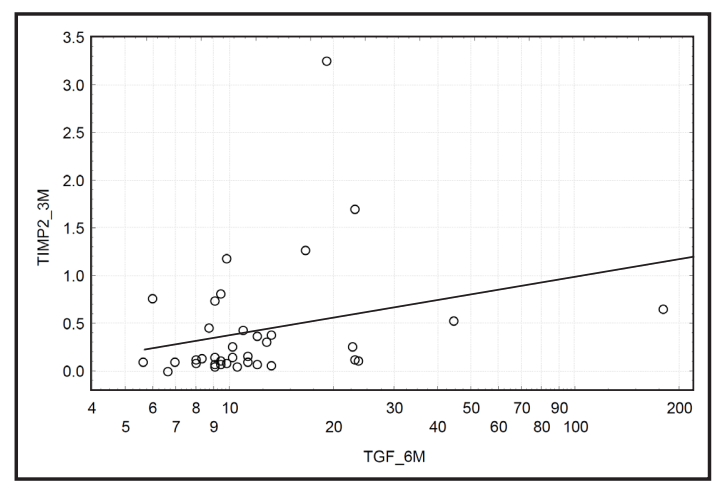

Fig. 4. The correlation between urine concentration of TIMP- 2 at 3 month and TGF- $\beta$ at 6 month $\mathrm{R}=0.33$, $\mathrm{p}=0.04$.

\section{Discussion}

Organs experience ischemia while being taken and stored for transplantation. This leads to complex pathophysiological disorders, which trigger inflammation in the given organ. Restoration of blood flow causes the damage to spread further. This condition is referred to as ischemia-reperfusion injury (IRI). IRI is the primary cause of acute renal failure and delayed graft function [10]. This phenomenon has a significant impact on early and long-term graft function. The typical morphologic picture of renal ischemic failure involves proximal tubule brush border loss, tubular epithelial cell loss, foci of dilated proximal tubules, casts in distal tubules and areas of tubular endothelium regeneration [11]. Despite the histopathological symptoms of renal tubular obstruction, it is not this disorder that affects renal function the most. Proximal tubules are known to be able to repair and revive their epithelium. This process enables the kidney to recover after an injury [12]. In summary, the main cause of acute renal failure is found in acute tubular necrosis, although IRI induces the release of proinflammatory cytokines, which damage the graft, initiating its fibrosis $[13,14]$. It is believed that the exacerbation of the inflammatory process and damage to the microcirculation play the most essential roles in irreversible renal damage. It has been found that following reperfusion, a considerable increase in MMP concentration occurs [15]. Inhibiting this increase reduces the scale of renal tissue damage secondary to IRI $[16,17]$. In our studies, we found that MMP-9 concentration in urine sampled at day 1 and month 3 after renal transplantation was negatively correlated with creatinine clearance in the shortterm post-transplant period (Table 3). MMP-2 did not affect early or long-term graft function expressed as creatinine clearance. Perhaps the lack of such a correlation was related to the preservation solution used during the cold ischemia period. In our centre, EC (Eurocollins) was used. In one experiment on rat kidneys, EC used for preservation purposes caused a smaller increase in MMP-2 concentration relative to MMP-9 concentration, compared with UW (University of Wisconsin) solution. Another author claims that such behaviour is related to the presence of cryptogenic inhibitors of metalloproteinases in preservation solutions [18]. It is known that MMP-9 is an acknowledged early marker of developing acute renal damage [19]. Nowak et al. performed an experiment on mice in which they induced IRI. Marimastat - an MMP inhibitor - was applied to the experimental group. In this group, lower concentrations of MMP-2 and MMP-9 were determined in urine and renal tissue, accompanied by a much smaller degree of necrotic damage to renal tubules and a lower creatinine content after IRI than in the control group [20]. Kunugi et al., also in mice, induced IRI in kidneys, applying an MMP-2 and MMP-9 inhibitor to the control group. In the control group, at hour 6 after reperfusion substantial increase in MMP-9 and MMP-2 concentration was observed, which was related to peritubular capillary destruction and basement 


\section{Kidney Blood Pressure Research}

Kidney Blood Press Res 2016;41:288-297

DOI: 10.1159/000443431

Published online: May 06, 2016

(C) 2016 The Author(s). Published by S. Karger AG, Base www.karger.com/kbr

membrane rupture. This led to bleeding into renal parenchyma and renal tubular damage by necrosis and apoptosis of their epithelium. In the experimental group, application of an inhibitor of metalloproteinases prior to IRI prevented such damage [21]. Other authors have shown a sudden growth in MMP concentration in other organs suffering from ischemia or ischemia and reperfusion, such as the brain, heart, liver or lungs [22-25]. Direct damage to peritubular capillaries is a recognized IRI mechanism stimulated by MMP. The elevated post-reperfusion MMP concentration, acting through different mechanisms, may contribute to the development of renal damage. By damaging the basement membrane of peritubular vessels, it destroys the barrier, leading to migration of inflammatory cells, which play a crucial role in the IRI process, to the extravascular space. It has been proven that damage to the vascular basement membrane along with interruption of its integrity is one of the main mechanisms behind renal damage. Reduced renal vascularization density secondary to IRI has been observed. It is known that the renal vascular system has a low regenerative capacity. Until day 40 after IRI, no growth in vascular density was observed [26]. The degradation of extracellular matrix, which is required for homeostasis to be maintained and for signals to be transmitted in the ischemic site, is another one of the mechanisms involved [22, 23]. Disordered homeostasis between cells and the extracellular matrix causes nerve cells to die in cases of cerebral ischemia $[27,28]$. The development of the inflammatory cascade is another MMP-stimulated mechanism behind IRI. MMP participates in activating it, or cooperates with various cytokines and chemokines [29, 30]. Apart from that, MMP-9 is an activator of IL-8, which is activated by cleavage and removal of a short amino acid sequence. IL-8 is a recognized neutrophil chemotactic factor. Secondly, MMP-9 activates a peptide originating from endothelial cells that activates neutrophils. This allows for a further spreading of the inflammatory process $[8,9,19]$. Research in rheumatoid arthritis has proved that MMP-9 inhibition reduces the production of various inflammatory factors, including IL-8.

MMP-9 contributes to chronic graft function. MMP-9 sampled both at day 1 and month 3 after renal transplantation is negatively correlated with creatinine clearance in long-term (four-year-long) observation (Table 3). This is evidence to the fact that the scale of postreperfusion damage to the kidney dependent on MMP-9 concentration determines longterm graft function. Gu et al. have noticed that elevated MMP-9 concentration in the early period of damage causes rupture of the basement membrane of the vessels, thus giving rise to proliferation and migration to the intima of vascular smooth muscle cells, which is the main lesion occurring at the initial stage of the development of chronic damage. Parenchymal infiltration by mononuclear cells is another factor characteristic of this period. The above study demonstrated a correlation between MMP-9 expression in the renal tissue and the size of infiltration by mononuclear cells. According to Gu et all., cellular matrix digestion favours the spreading of infiltration, which in turn is responsible for renal fibrosis. Moreover, TGF- $\beta$ is a key factor responsible for renal fibrosis [31]. In our study, we determined TGF- $\beta$ in urine at 6 and 12 months after renal transplantation, i.e., the time when, according to Nankivell, chronic lesions are already present in repeated protocol biopsies [32]. We identified a positive correlation between MMP-9 concentration in urine at day 1 after renal transplantation and TGF- $\beta$ concentration in urine at month 12 after transplantation. On the one hand, this means that damage caused after reperfusion by an elevated concentration of MMP-9 stimulates late fibrosis. On the other hand, TGF- $\beta$ is an acknowledged MMP-9 activator and perhaps its concentration is increased already in the first hours following reperfusion, stimulating MMP-9 [33]. Unfortunately, we did not determine TGF-B in the early post-transplant period. What is more, MMP concentration in urine at day 1 was positively - albeit nonsignificantly - correlated with tubular atrophy and parenchymal fibrosis in renal biopsies performed at months 3 and 12 after renal transplantation. This statistical insignificance may result from the small number of renal biopsies carried out: not all of the patients examined had renal biopsies performed on them. When writing about chronic renal function, it is advisable to add that the MMP- 2 concentration we determined at day 1, month 3 and after year 1 did not affect creatinine clearance, but its concentration at month 3 was correlated with the value of 


\section{Kidney Blood Pressure Research}

Kidney Blood Press Res 2016;41:288-297

DOI: 10.1159/000443431

Published online: May 06, 2016

(C) 2016 The Author(s). Published by S. Karger AG, Base

www.karger.com/kbr

proteinuria at day 1 , month 3 and after year 1 following renal transplantation. Proteinuria is a marker of damage to different elements of the nephron, and it may also result from chronic renal damage caused by IF/TA. In their research on renal transplants, Lutz et al. observed that early MMP-2 inhibition reduces proteinuria, which was parallel to a milder severity of the chronic lesions [34]. This proves that MMP-2, as a marker of proteinuria, has an indirect influence on chronic lesions in the transplanted kidney. In our studies, it was mainly the gelatinase MMP-9 that was responsible for renal damage and for early and long-term renal function. In her research on MMP-2 and MMP-9 concentration after renal transplantation, Kuyvenhoven et al. only observed an increase in MMP-9 concentration and a correlation between its concentration and renal damage secondary to IRI [35].

In our research, we also determined the content of TIMP-1, the inhibitor of MMP-9, and the content of TIMP-2, the inhibitor of MMP-2. concentration of TIMP is contrary to that of MMP, therefore it would appear that they should have an opposite effect on early and longterm graft function. However, in our studies, an increase in the concentration of both MMP-9 and TIMP-1 has the same negative impact on renal function. This may stem from the fact that TMIP1 reflects MMP-9 concentration as its content grows, along with an increase in metalloproteinase concentration. Furthermore, TIMP transcription is regulated by the same cytokines and growth factors as MMP expression [36]. Proof of this mechanism is found in the statistically significant correlation between the activities of MMP-9 and TIMP-1 at day 1, month 3 and month 12 after renal transplantation (Table 4). TIMP-1 concentration in urine sampled at day 1 was negatively correlated with creatinine clearance in the early post-transplant period: days 1, 7 and 14. Likewise, TIMP-1 sampled at month 3 after renal transplantation was correlated with early (days 7 and 14) and late (3 months and 2 years) graft function after renal transplantation. TIMP-1 concentration in urine sampled 1 year after renal transplantation was also negatively correlated with creatinine clearance 1 year and 2 years after renal transplantation, although the correlation was not statistically significant ( $p$ $=0.08$ and $p=0.06$, respectively) (Table 3). TIMP- 2 concentration in urine sampled at day 1 after transplantation did not have any statistically significant influence on early or long-term graft function. TIMP-2 concentration in urine sampled 3 months after renal transplantation was negatively correlated with creatinine clearance at days 7 and 14, as well as 2 years after transplantation (Table 4).

However, its concentration in urine sampled 1 year after renal transplantation turned out to be a marker of long-term renal function, negatively correlated with creatinine clearance 1, 2 and 3 years after renal transplantation. TIMP- 2 concentration in urine sampled at month 3 was positively correlated with proteinuria 1 year after renal transplantation, which is known to be a marker of various graft injuries, including those related to IF/TA. Additionally, the concentration of TIMP-1 and -2 may be deemed to be a marker of early renal graft damage, as in our studies the contents of TIMP- 1 in urine sampled at day 1 and month 3 after transplantation and TIMP- 2 in urine sampled at month 3 after transplantation were higher in the group demonstrating DGF. In his research on renal biopsy specimens, Kusaka et al. found that a high content of TIMP-1 was a marker of delayed graft function and the need for hemodialysis [37].

\section{Conclusion}

Early post-transplant MMP-9 concentration is an essential marker of early and longterm renal graft function. Its increased concentration in urine at day one after renal transplantation was connected with worse early (days 1, 7 and 14) and long-term renal function - at years 1, 2, 3 and 4 (renal function was evaluated by eGFR which was calculated using the CKD-EPI Formula with the help of the National Kidney Foundation calculator, and the creatinine level was evaluated from blood samples). Moreover its increased concentration was correlated with lesions related to tubular atrophy and fibrosis in renal 


\section{Kidney \\ Blood Pressure Research}

Kidney Blood Press Res 2016;41:288-297

DOI: 10.1159/000443431

Published online: May 06, 2016

(C) 2016 The Author(s). Published by S. Karger AG, Base

www.karger.com/kbr

biopsies performed at months 3 and 12 after renal transplantation. Its concentration was correlated with TGF- $\beta$ content in later periods (at month 12) - which is proof of chronic fibrosis induction by the activated MMP-9. TIMP- 1 and -2 are primarily markers of early graft function-their elevated concentrations at day 1 and 3 after transplantation were related to a worse eGFR at day 1, 7 and 14. In the DGF group, their concentrations were higher. Early post-transplant MMP-2 concentration is a marker of proteinuria in the early (days 1 and 30 ) and long-term (month 12) post-transplant period, which is known to be a marker of various graft injuries, including those related to IF/TA. TIMP- 1 and -2 at days 1 and 30 after transplantation is connected with a higher TGF- $\beta$ concentration in urine at months 6 and 12 into the post-transplant period.

\section{Disclosure Statement}

The authors of this manuscript state that they do not have any conflict of interests and nothing to disclose.

\section{References}

1 Eltzschig HK, Collard CD: Vascular ischaemia and reperfusion injury. Br Med Bull 2004;70:71-86.

2 Conger JD, Robinette JB, Hammond WS: Differences in vascular reactivity in models of isc hemic acute renal failure. Kidney Int 1991;39:1087-1097.

3 Conger JD, Weil JV. Abnormal vascular function following ischemia-reperfusion injury. J Investig Med 1995;43:431-442.

4 Sheridan AM, Bonventre JV: Cell biology and molecular mechanisms of injury in ischemic acute renal failure. Curr Opin Nephrol Hypertens 2000;9:427-434.

5 Yamamoto T, Tada T, Brodsky SV, Tanaka H, Noiri E, Kajiya F, Goligorsky MS: Intravital videomicroscopy of peritubular capillaries in renal ischemia. Am J Physiol Renal Physiol 2002;282:1150-1155.

6 Friedewald JJ, Rabb H: Inflamatory cells in ischemic acute renal failure. Kidney Int 2004;66:486-490.

7 Singbartl K, Ley K: Leukocyte recruitment and acute renal failure. J Mol Med 2004;82:91-101.

8 Awad AS, Rouse M, Huang L, Vergis AL, Reutershan J, Cathro HP, Linden J, Okusa MD: Compartmentaliazation of neutrophils in the kidney and lungfollowing acute ischemic injury. Kidney Int 2009;75:689-698.

9 Jang HR, Rabb H: The innate immune response in ischemic acute kidney injury. Clin Immunol 2009;130:4150.

10 Shoskes DA, Halloran PF: Delayed graft function in renal transplantation: etiology, management and longterm significance. J Urol 1996;155:1831-1840.

11 Racusen LC: The morphologic basis of acute renal failure. Molitoris BA, Finn WF (eds) In: Acut Renal Failure. W.B. Saunders, Philadelphia, 2001, pp 1-12.

12 Humes HD, Liu S: Cellular and molecular basis of renal repair in acute renal failure. J Lab Clin Med 1994;124:749-754.

13 Paul LC: Chronic renal transplant loss. Kidney Int 1995;47:1491-1499.

14 Azuma H, Nadeau K, Takada M, Mackenzie HS, Tilney NL: Cellular and molecular predictors of chronic renal dysfunction after initial ischemia/reperfusion injury of single kidney. Tranplantation 1997;64:190-197.

15 Winn RK, Ramamoorthy C, Vedder NB, Sharar SR, Harlan JM: Leukocyte-endothelial cell interaction in ischaemia-reperfusion ijury. Ann N Y Acad Sci 1997:832:311-321.

16 Matsumoto H, Koga H, Iida M, Tarumi K, Fujita M, Haruma K: Blockade of tumor necrosis factorhaconverting enzyme improves experimental small intestinal damage by decreasing matrix metalloproteinase-3 production in rats. Scand J Gastroenterol 2006;41:1320-1329.

17 Bergers G, Javaherin K, Lo KM, Folkman J, Hanahan D: Effects of angiogenesis inhibitors on multistagecarcinogenesis in mice. Science 1999;284:808-812. 


\section{Kidney \\ Blood Pressure Research}

Kidney Blood Press Res 2016;41:288-297

DOI: 10.1159/000443431

Published online: May 06, 2016

(C) 2016 The Author(s). Published by S. Karger AG, Base

www.karger.com/kbr

18 Sulikowski T, Domanski L, Zietek Z, Adler G, Pawlik A, Ciechanowicz A, Ciechanowski K, Ostrowski M: Effect of preservation solution UW and EC on the expression of matrix Metalloproteinase II and tissue inhibitor of metalloproteinase II genes in rat kidney. Postep Hig Med Dosw 2012;66:45-50.

19 Lipka D, Boratyński J: Metalloproteinases. Structure and function. Postepy Hig Med Dosw 2008;62:328336.

20 Novak BK, Le HD, Christison-Lagay ER, Nose V, Doiron RJ, Moses MA, Puder M: Effect of metalloproteinase inhibition in murine model of renal ischemia reperfusion ijury. Pediatr Res 2010;67:257-262.

21 Kunugi S, Shimizu A, Kuwahara N, Du X, Takahashi M, Terasaki Y, Fujita E, Mii A, Nagasaka S, Akimoto T, Masuda Y, Fukuda Y: Inhibition of matrix metalloproteinase reduces ischemai-reperfusion acute kidney injury. Lab Invest 2011;91:170-180.

22 Rosell A, Lo EH: Multiphasic role for matrix metalloproteinases after sroke. Curr Opin Pharmacol 2008;8:82-89.

23 Chow AK, Cena J, Schulz R: Acute action and novel target of matrix metalloproteinases in the heart and vasculature. Br J Pharmacol 2007;152:189-205.

24 Viappiani S, Sariahmetoglu M, Schulz R: The role of matrix metalloproteinase inhibitors in ischamiareperfusion injury in the liver. Curr Pharm Des 2006;12:2923-2934.

25 Soccal PM, Gasche Y, Miniati DN, Hoyt G, Berry GJ, Doyle RL, Theodore J, Robbins RC: Matrix metalloproteinase inhibition decreases ischemia-reperfusion injury after lung transplanttion. Am J Transplant 2004;4:41-50.

26 Basile DP, Donohoe DL, Roethe K, Osborn J: Renal Ischemic injuryresult in permanent damageto peritubular capillarie and influences long-term function. Am J Physiol Renal Physiol 2001;281:887-899.

27 Gu Z, Kaul M, Yan B, Kridel SJ, Cui J, Strongin A, Smith JW, Liddington RC, Lipton SA: S-nitrosylation of matrix metalloproteinases: signaling pathway to neuron al cell Heath. Science 2002;297:1186-1190.

28 Lee SR, Lo EH: Induction of capsace-mediated cell Heath by matrix-metalloproteinases in cerebral endothelial cells after hypoxia reoxygenation. J CerebBlood Flow Metab 2004;24:720-727.

29 Gill SE, Parks WC: Metalloproteinases as modulators of wound healing. Int J Biochem Cell Biol 2008;40:1334-1347.

30 Fukuda Y, Ishizaki M, Kudoh S, Kitaichi M, Yamanaka N: Localization of matrix metalloproteinases 1,2 and 9 and tissue inhibitor of metalloproteinase-2 in interstitial lung diseases. Lab Invent 1998;78:687-698.

31 Gu D, Shi Y, Ding Y, Liu X, Zou H. Dramatic early event in chronic allograft nephropathy: increased but not decreased expression of MMP-9 gene. Diagn Pathol 2013;8:13.

32 Nankivell BJ, Borrows RJ, Chir B, Fung CL, O'Connell PJ, Allen RD, Chapman JR: The natural history of chronic allograft nephropathy. N Engl J Med 2003;349:2326-2333.

33 Kalembeyi I, Inada H, Nishura R, Imanaka-Yoshida K, Sakakura T, Yoshida T: Tenascin-C upregulates matrix metalloproteinase-9 9n breast cancer cells: direct and synergistic effects with transforming growth factor beta1. Int J Cancer 2003;105:53-60.

34 Lutz J, Yao Y, Song E, Antus B, Hamar P, Liu S, Heemann U: Inhibition of matrixe metaloproteinases during chronic allograft nephropathy in rats. Transplantation 2005;79:655-661.

35 Kuyvenhoven JP, Molenaar IQ, Verspaget HW, Veldman MG, Palareti G, Legnani C, Moolenburgh SE, Terpstra OT, Lamers CB, van Hoek B, Porte RJ: Plasma MMP-2 and MMP-9 and their inhibitors TIMP-1 and TIMP2 during human orthotopic liver transplantation. The effect of aprotinin and the relation to ischemia/ reperfusion injury. Thromb Haemost 2004;91:506-513.

36 Norman JT, Lewis MP: Matrix metalloproteinases (MMPs) in renal fibrosis. Kidney Int Suppl 1996;54:6163.

37 Kusaka M, Kuroyanagi Y, Ichino M, Sasaki H, Maruyama T, Hayakawa K, Shiroki R, Sugitani A, Kurahashi H, Hoshinaga K: Serum tissue inhibitor of metalloproteinases 1 (TIMP-1) predicts organ recovery from delayed graft function after kidney transplantation from donors after cardiac death. Cell Transplant 2010;19:723-729. 